\title{
Sarcoma in an Atrophic Eye
}

\author{
P.A. \\ ten Thije $\dagger$
}

A 66-year-old man had an atrophic eye following herpes corneae at the age of 36. He had been completely blind for 20 years; before that the visual acuity had been 5/20 with correction. After an absence of many years, the patient reappeared for glasses. The left eye was normal, myopic, visual acuity with correction 5/5. The right eye had a shallow anterior chamber, posterior synechiae, total cataract, and visual acuity 0 .

Two years later some vascular injection was seen in the right eye. Scopol-amine did not have much effect, but a few weeks later a marked exophthal-mos developed in an hour's time.

Arteriography and examination by the ear, nose and throat specialist revealed no anomaly. On operating, necrotic-looking tissue was removed from the orbit above the eye, microscopic examination showed this to be derived from a polymorphous sarcoma. Evisceration of the orbit revealed that the nasal wall had already been involved. Radiation treatment could not prevent the death of the patient a few months later.

Microscopic examination revealed an eye containing much connective tissue, with a dislocated lens, calcareous plaques, slits left by cholesterol crystals, hyperplasia of the retina, and much necrotic tissue, in which, in some places, a large-celled sarcoma could be seen. The sclera had been penetrated. Outside the eye the tumour had originally been of the same type, with necrosis and cells with large pale nuclei with a well-defined nucleolus, but as the tumour extended into the orbit the nuclei became richer in chromatin and the growth became more irregular. There was no pigment in the tumour, so it must be regarded as a sarcoma in an atrophic eye. Other possibilities, such as a primary orbital tumour which has grown into the eye, or a melano-tumour which has penetrated later, are very improbable.

Not much has been written on this subject. Reese mentions a case of Ewing's; this was a personal communication and could not be traced further. Only Sattler in his textbook 'Die bösartigen Ge-schwülste des Auges' says that a sarcoma can develop in a phthisic eye. He says that this is 'durch einige zuverlässige Beobachtungen sichergestellt' without mentioning where these reliable reports can be found. 